\title{
Model Kontrol Keimigrasian dalam Mencegah Tindak Pidana Terorisme di Indonesia
}

\author{
Harison Citrawan \\ Ministry of Law and Human Rights, Indonesia \\ harison.citrawan@kemenkumham.go.id
}

Sabrina Nadilla

Ministry of Law and Human Rights, Indonesia

sabrinadesu@yahoo.com

\begin{abstract}
This article attempts to elaborate an immigration control model that is capable in preventing terrorist activities in Indonesia. By observing several terrorism case-laws, this study draws a nexus between terrorism and several aspects within immigration, including passport issuance, border control, foreigner surveillance, and visa and entry permit issuance. Technically, in relation to such a nexus, this study finds that the current immigration control model is built upon three elements of duty: namely intelligence, surveillance, and border control. In principle, these three elements ought to be executed as an interconnected cycle. Consequently, a preventive control model should be circular, in the sense that any activities between elements of duty cannot be separated from one another. In order to become an established terrorism prevention mechanism, this control model requires information and data exchange amongst the immigration units. Moreover, any involvements from other institutions, such as police, BNPT, BIN, and NCB-Interpol are also preconditioned to ensure the efficacy of the circular model.
\end{abstract}

KEYWORDS: Immigration, Control, Terrorism.

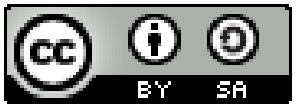

Copyright $\odot 2019$ by Author(s)

This work is licensed under a Creative Commons Attribution-ShareAlike 4.0 International License. All writings published in this journal are personal views of the authors and do not represent the views of this journal and the author's affiliated institutions.

\section{HOW TO CITE:}

Citrawan, Harison \& Sabrina Nadilla. "Model Kontrol Keimigrasian dalam Mencegah Tindak Pidana Terorisme di Indonesia" (2019) 6:1 Lentera Hukum 71-96.

Submitted: February 19, 2019 Revised: March 10, 2019 Accepted: April 28, 2019 


\section{PENDAHULUAN}

Fenomena tindak pidana terorisme yang mengemuka belakangan ini memiliki relevansi yang erat dengan tugas dan fungsi Kementerian Hukum dan HAM, khususnya fungsi keimigrasian, mengingat isu tentang foreign terrorist fighters (FTF) menjadi tema krusial di tingkat global, regional, maupun nasional. ${ }^{1}$ Berbagai riset sudah menunjukkan bahwa terdapat relasi yang erat antara perpindahan orang (migrasi) dengan kemungkinan terjadinya tindakan terorisme. ${ }^{2}$ Dalam praktiknya, Direktorat Jenderal Imigrasi telah melakukan kerjasama dengan Interpol guna memeriksa orang-orang, khususnya warga negara Indonesia, yang diduga bergabung dengan FTF dengan modus perjalanan pariwisata ke negara tertentu sebagai tempat transit.

Secara normatif, berdasarkan UU No. 6/2011 tentang Keimigrasian, keimigrasian didefinisikan sebagai hal ihwal lalu lintas orang yang masuk atau keluar Wilayah Indonesia serta pengawasannya dalam rangka menjaga tegaknya kedaulatan negara. ${ }^{3}$ Lebih lanjut, fungsi keimigrasian diartikan sebagai "bagian dari urusan pemerintahan negara dalam memberikan pelayanan Keimigrasian, penegakan hukum, keamanan negara, dan fasilitator pembangunan kesejahteraan masyarakat." ${ }^{4}$ Dua ketentuan ini dapat dikaitkan dengan UU No. 3/2002 tentang Pertahanan Negara yang menempatkan terorisme sebagai salah satu bentuk permasalahan keamanan yang dapat mengancam kedaulatan negara. ${ }^{5}$ Kendati komunitas internasional gagal bersepakat untuk menetapkan terorisme sebagai kejahatan yang luar biasa (extraordinary crime), politik hukum Indonesia sudah mengatur hal demikian melalui kebijakan normatif yang ada saat ini. ${ }^{6}$ Sebagai konsekuensi, pemerintah tentu memerlukan langkah-langkah yang luar biasa pula dalam penanganan kasus-kasus tindak pidana terorisme yang ada. ${ }^{7}$

Salah satu peran penting keimigrasian dalam pencegahan tindak pidana terorisme ialah melalui laporan intelijen keimigrasian. Berdasarkan regulasi tentang pemberantasan terorisme, diatur bahwa: "Untuk memperoleh bukti permulaan yang cukup, penyidik dapat menggunakan setiap laporan intelijen dari Kepolisian, Kejaksaan, Direktorat Jenderal Imigrasi, Direktorat Jenderal Bea dan Cukai, Tentara Nasional Indonesia, Badan Intelijen Negara, Departemen Luar Negeri, Departemen Dalam Negeri atau instansi lain yang terkait." 8 Dalam konteks demikian, tentu diperlukan langkah yang lebih taktis tentang bagaimana fungsi keimigrasian dapat

1 United Nations Office on Drugs and Crime, Foreign Terrorist Fighters: Manual for Judicial Training Institutes South-Eastern Europe (Vienna: United Nations, 2017).

2 Teresa Miller, "Blurring the Boundaries Between Immigration and Crime Control After September llth" (2005) 25:1 Boston Coll Third World Law J 81; Vincenzo Bove \& Tobias Böhmelt, "Does Immigration Induce Terrorism?" (2016) J Polit; Nora V Demleitner, "Immigration Threats and Rewards: Effective Law Enforcement Tools in the “War' on Terrorism?” (2002) 51 Emory Law J 1059.

3 Pasal 1 angka 1 Undang-Undang Nomor 6 Tahun 2011 tentang Keimigrasian.

Pasal 1 angka 3 Ibid.

5 Penjelasan Pasal 7 Ayat (2) UU 3/2002 tentang Pertahanan Negara.

6 Vidya Prahassacitta, "The Concept of Extraordinary Crime in Indonesia Legal System: Is the Concept an Effective Criminal Policy?" (2016) 7:4 Humaniora 513.

7 United Nations Office on Drugs and Crime, Handbook on Criminal Justice Responses to Terrorism, Criminal Justice Handbook Series (New York: United Nations, 2009).

8 Pasal 26 UU 15/2003 tentang Pemberantasan Terorisme [UU 15/2003 tentang Pemberantasan Terorisme]. 
berkontribusi terhadap pencegahan tindak pidana terorisme yang berafiliasi atau terkait dengan FTF. ${ }^{9}$

Pada tataran praktis, salah satu instrumen yang dapat dikembangkan ialah terrorism risk analysis dalam fungsi keimigrasian yang didasarkan pada sembilan parameter, yakni: (i) sifat dari tindakan permusuhan, (ii) motivasi, (iii) tujuan, (iv) rencana untuk melakukan kekerasan, (v) peran dari para informan, (vi) jaringan, (vii) hubungan dengan kelompok kekerasan ekstrim, (viii) cakupan media, serta (ix) relevansi dengan internet. ${ }^{10}$ Pada derajat tertentu, parameter tersebut dapat diterjemahkan secara lebih konkret dalam konteks pelaksanaan fungsi intelijen keimigrasian dalam menilai tingkat risiko ancaman terorisme pada individu tertentu yang keluar dan masuk Wilayah Indonesia. Selain itu, parameter tersebut juga dapat diterapkan dalam konteks pengawasan keimigrasian. ${ }^{\text {ll }}$

Sejalan dengan logika fungsi intelijen keimigrasian yang diterangkan sebelumnya, aspek lain yang memiliki kaitan erat dengan pencegahan kejahatan terorisme ialah kebijakan entry clearance. Terkait hal tersebut, Pasal 9 UU 6/201l mengatur bahwa "(1) Setiap orang yang masuk atau keluar Wilayah Indonesia wajib melalui pemeriksaan yang dilakukan oleh Pejabat Imigrasi di Tempat Pemeriksaan Imigrasi." Adapun berdasarkan ayat (2), "pemeriksaan dilakukan atas Dokumen Perjalanan dan/atau identitas diri yang sah." Dalam hal ini, terdapat klausul pengaman bila terjadi keraguan atas keabsahan Dokumen Perjalanan dan/atau identitas diri seseorang, yakni dengan memberikan wewenang kepada Pejabat Imigrasi untuk melakukan penggeledahan terhadap badan dan barang bawaan, dan dapat pula dilanjutkan dengan proses penyelidikan Keimigrasian.

Terkait hal ini pula, Pasal 13 memberikan kewenangan bagi Pejabat Imigrasi untuk menolak orang asing yang terlibat kejahatan internasional dan tindak pidana transnasional terorganisasi, termasuk kejahatan terorisme. (Lih. Penjelasan Ps. 13) Dalam prosesnya, orang asing tersebut "ditempatkan dalam pengawasan", yakni di Rumah Detensi Imigrasi atau Ruang Detensi Imigrasi atau ruang khusus dalam rangka menunggu keberangkatannya keluar Wilayah Indonesia. (Ps. 13 (2))

Di sisi lain, dalam konteks keluarnya orang dari wilayah Indonesia, Pasal 15 UU 6/2011 mengatur bahwa "Setiap orang dapat keluar Wilayah Indonesia setelah memenuhi persyaratan dan mendapat Tanda Keluar dari Pejabat Imigrasi." Selanjutnya Pasal 16 memberikan wewenang bagi Pejabat Imigrasi untuk menolak orang keluar Wilayah Indonesia bila, salah satunya, diperlukan untuk kepentingan penyelidikan dan penyidikan atas permintaan pejabat yang berwenang, atau mereka yang tercantum dalam daftar pencegahan. (Pasal 16 (l) huruf b dan c)) Berdasarkan kerangka normatif yang ada, tentu terdapat peluang bagi pelaksana fungsi keimigrasian untuk mengantisipasi dan mencegah kejahatan terorisme melalui proses entry clearance, yang

Bab IV jo. Pasal 74 UU 6/2011 tentang Keimigrasian, supra note 3.

10 John Mueller (ed), Terrorism Since 9/11: The American Cases (Washington: The Educational Publisher, 2018).

11 Pasal 66 UU 6/2011 tentang Keimigrasian, supra note 3. 
merupakan wewenang Pejabat Imigrasi. ${ }^{12}$ Dalam konteks tersebut, diperlukan kolaborasi yang efektif antara Direktorat Jenderal Imigrasi dengan instansi lain yang relevan terhadap penanganan kejahatan terorisme, seperti Kepolisian, BNPT, dan BIN, dalam memeriksa secara lebih mendalam orang yang diduga terlibat kejahatan tersebut. Kolaborasi yang efektif ini dapat dilakukan di area imigrasi, yakni di tempat pemeriksaan imigrasi, dengan ragam upaya koordinasi dan pertukaran informasi antar instansi. $^{13}$

Berdasarkan latar belakang tersebut, masalah utama yang dapat diidentifikasi yakni tindak pidana terorisme di Wilayah Indonesia tidak terlepas dari fenomena FTF di tingkat global. Pada saat yang sama, migrasi atau perpindahan orang dari dan ke Wilayah Indonesia perlu menjadi perhatian khusus dari Kementerian Hukum dan HAM, utamanya melalui fungsi intelijen dan pengawasan keimigrasian, serta pemeriksaan masuk dan keluar Wilayah Indonesia.

Mengingat arti penting dari hal-hal tersebut, artikel ini hendak mengelaborasi secara lebih detil tentang metode kontrol keimigrasian yang ada dalam rangka mencegah terjadinya kejahatan terorisme di Indonesia. Secara analitik, fokus studi ini setidaknya mencakup tiga aspek utama dalam fungsi keimigrasian, yakni langkah pengawasan, intelijen, serta pemeriksaan orang yang keluar dan masuk wilayah Republik Indonesia. Untuk dapat memberikan alternatif model kontrol yang dapat dilaksanakan oleh pemerintah, studi ini pertama-tama menggambarkan beberapa evidensi terkait relasi antara kejahatan terorisme di Indonesia dengan kelompok teroris yang ada di luar negeri.

Setelah itu, diperlukan pula penggambaran pola keluar dan masuknya terduga teroris, serta identifikasi terhadap ruang gerak yang mungkin ditangani oleh pihak Imigrasi. Terakhir, kajian ini juga akan menggambarkan praktik-praktik yang telah dilakukan oleh negara-negara lain dalam mencegah kejahatan terorisme, serta sedapat mungkin mengkonstekstualkan temuan tersebut dengan regulasi nasional di Indonesia. Adapun dalam pengumpulan data, kajian ini mengumpulkan data primer dari hasil wawancara dengan narasumber terkait, seperti pejabat imigrasi dan aparat kepolisian, serta menggunakan data sekunder yang tersedia dalam jurnal, buku, periodicals, regulasi, hingga berita di media cetak dan dalam jaringan.

\section{MOBILITAS GLOBAL DAN TERORISME DI INDONESIA}

Relasi antara mobilitas global dan terjadinya kejahatan transnasional seperti terorisme telah diulas dari beragam perspektif, baik yang memandangnya sebagai ancaman keamanan tradisional maupun non-tradisional. ${ }^{14}$ Dalam praktiknya, terdapat berbagai jenis kebijakan dan restriksi keimigrasian yang diterapkan oleh negara guna mencegah

12 Gina Clayton, "The UK and Extraterritorial Immigration Control: Entry Clearance and Juxtaposed Control," in Extraterritorial Immigration Control: Legal Challenges, ed. Bernard Ryan and Valsamis Mitsilegas (Leiden, Boston: Martinus Nijhoff Publishers, 2010), 397-430.

13 MA Syahrin, "Menakar Kedaulatan Negara dalam Perspektif Keimigrasian" 18:1 J Penelit Huk Jure 43.

14 Katja F Aas, Globalization and Crime (London: SAGE Publications, 2007). 
terjadinya kejahatan terorisme di negaranya, baik berupa peningkatan kontrol perbatasan dan masuknya orang (border and entry control), dan beberapa ragam strategi kontrol di luar wilayahnya (offshore control). ${ }^{15}$ Dalam konteks tersebut, Koslowski berpendapat bahwa ${ }^{16}$

International migration is not the "new security issue," it is the growing cross-border movements of products, money, conveyances, people (and the micro-parasites they carry) that may be instruments of international terrorism. Nevertheless, international migration may play a role in enabling certain forms of political violence, failures of economic and social integration of migrants may have contributed to their taking a violent path and some migrants have become prominent terrorists.

Berdasarkan pandangan tersebut, dapat dipahami bahwa mobilitas internasional mengisyaratkan dua hal yang saling bertautan, yakni di satu sisi negara-negara berkembang, seperti Indonesia, ingin mendorong terciptanya pemasukan (revenue) dari kemudahan mobilitas yang ada, namun di sisi yang lain, mobilitas tersebut dapat menjadi instrumen untuk terjadinya kejahatan terorisme internasional. Kondisi demikian secara langsung menuntut negara untuk merumuskan kebijakan kontrol keimigrasian secara proporsional berdasarkan kepentingan nasional. Frasa 'kontrol' dalam hal ini dipilih agar tidak terjebak pada reduksi fungsi imigrasi untuk mengawasi lalu lintas orang keluar dan masuk wilayah Indonesia. Kontrol keimigrasian dengan begitu mengandung elemen-elemen yang lebih komprehensif ketimbang pengawasan, yakni mencakup administrasi keimigrasian, pengawasan, intelijen, hingga penegakan hukum keimigrasian. ${ }^{17}$

Secara global berdasarkan indeks dampak terorisme (Global Terrorism Index/GTI) yang dirilis oleh Institute for Economics and Peace, Indonesia menduduki posisi negara dengan dampak moderat dengan nilai 4.55 pada 2016, dan diprediksi turun menjadi 4.40 dan 4.10 pada 2018 dan 2020. Laporan GTI 2017 tersebut juga mengidentifikasi bahwa salah satu kelompok yang menjadikan Indonesia sebagai lokasi penyerangan adalah ISIS atau ISIL. ${ }^{18}$ Dengan demikian, Indonesia pada level tertentu mengalami dampak negatif dari tingginya arus perpindahan orang dalam bentuk kejahatan terorisme transnasional. Melihat fenomena tersebut sebagai latar belakang, analisis akan dilanjutkan pada tipologi kejahatan terorisme di Indonesia dalam perspektif keimigrasian.

15 IOM, International Terrorism and Migration (International Organization for Migration, 2003).

16 Rey Koslowski, "Immigration, Crime and Terrorism” in Marc R Rosenblum \& Daniel J Tichenor, eds, Oxf Handb Int Migr (Oxford University Press, 2012).

17 John Torpey, The Invention of the Passport: Surveillance, Citizenship and the State (Cambridge: Cambridge University Press, 2000), pp. 6-10.

18 Institute of Peace and Economics, Global Terrorism Index 2015 Measuring and Understanding the Impact of Terrorism, hlm. 73, tersedia pada laman http:/visionofhumanity.org/app/uploads/2017/11/GlobalTerrorism-Index-2017.pdf terakhir diakses pada 25/9/2018. 


\section{A. Membangun Konteks: Tindak Pidana Terorisme di Indonesia}

Pembahasan tentang model kontrol imigrasi dalam pencegahan tindak pidana terorisme di Indonesia perlu pertama-tama meninjau hubungan atau relasi antara fenomena kejahatan tersebut dengan fungsi keimigrasian. Untuk itu, kajian ini melakukan penelusuran terhadap beberapa putusan pengadilan atas kasus tindak pidana terorisme yang terjadi di berbagai wilayah di Indonesia, untuk kemudian mengidentifikasi aspek keimigrasian di masing-masing kasus. Adapun penelusuran terhadap putusan pengadilan ini didasarkan pada ketersediaan putusan di dalam situs direktori putusan Mahkamah Agung (putusan.mahkamahagung.go.id). Putusan pengadilan yang berhasil dihimpun adalah sebagai berikut.

Tabel 1 .

Daftar Putusan Pengadilan tentang Tindak Pidana Terorisme

\begin{tabular}{|c|c|c|}
\hline Register & Pelaku & Kebangsaan \\
\hline $\begin{array}{l}\text { Mahkamah Agung RI No. } \\
2134 \mathrm{~K} / \mathrm{Pid} / 2006\end{array}$ & $\begin{array}{l}\text { Idi Amin Thabrani Pattimura alias } \\
\text { Ongen }\end{array}$ & WNI \\
\hline $\begin{array}{l}\text { Mahkamah Agung RI No. } 93 \\
\text { PK/Pid.Sus/2016 }\end{array}$ & $\begin{array}{l}\text { Abu Bakar bin Abud Baasyir alias } \\
\text { Abu Bakar Baasyir }\end{array}$ & WNI \\
\hline $\begin{array}{lrr}\text { Pengadilan Tinggi } & \text { DKI } \\
\text { Jakarta } & & \text { No. } \\
\text { 117/PID/2011/PT.DKI } & \end{array}$ & $\begin{array}{l}\text { Yudi Zulfahri alias Barro bin M. } \\
\text { Daud Basa'a }\end{array}$ & WNI \\
\hline $\begin{array}{l}\text { Mahkamah Agung RI No. } \\
127 \text { PK/PID.SUS/2010 }\end{array}$ & Rusli Amiludi alias Rusli & WNI \\
\hline $\begin{array}{l}\text { Mahkamah Agung RI No. } \\
167 \text { PK/Pid.Sus/2013 }\end{array}$ & $\begin{array}{l}\text { Taufik Bin Marzuki alias Abu } \\
\text { Sayaf Alex Nurdin Sulaiman bin } \\
\text { Tarmizi }\end{array}$ & WNI \\
\hline $\begin{array}{l}\text { Mahkamah Agung RI No. } \\
169 \text { PK/PID.SUS/2013 }\end{array}$ & Masykur Rahmat bin Mahmud & WNI \\
\hline $\begin{array}{l}\text { Mahkamah Agung RI No. } \\
170 \text { PK/PID.SUS/2013 }\end{array}$ & $\begin{array}{l}\text { Agam Fitriady alias Syamil alias } \\
\text { Afit }\end{array}$ & WNI \\
\hline $\begin{array}{l}\text { Mahkamah Agung RI No. } \\
384 \text { K/PID.SUS/2014 }\end{array}$ & $\begin{array}{l}\text { Muhammad Yani alias Pak E alias } \\
\text { Ali alias Soni Hermawan alias M. } \\
\text { Ali Basya }\end{array}$ & WNI \\
\hline $\begin{array}{l}\text { Mahkamah Agung RI No. } \\
1068 \text { K/PID/2005 }\end{array}$ & $\begin{array}{l}\text { Sarip Hidayat alias Dayat bin } \\
\text { Buhari; Kamaludin bin Khasan; } \\
\text { Septiono Kardhian Widiarto bin } \\
\text { Karyono alias Amar alias Widi }\end{array}$ & WNI \\
\hline $\begin{array}{l}\text { Mahkamah Agung RI No. } \\
1423 \text { K/PID.SUS/2016 }\end{array}$ & $\begin{array}{l}\text { Dedi Hernanda Nasution alias } \\
\text { Nanda }\end{array}$ & WNI \\
\hline $\begin{array}{l}\text { Mahkamah Agung RI No. } \\
\text { 1497/K/PID.SUS/2013 }\end{array}$ & $\begin{array}{l}\text { Cahya Fitriyanta alias Fadliansyah } \\
\text { alias Edi Saputra alias Angga Eka }\end{array}$ & WNI \\
\hline
\end{tabular}




\begin{tabular}{|l|l|l|}
\hline & $\begin{array}{l}\text { Putra alias Reno Erlangga alias } \\
\text { Ronny Setiawan alias Anas } \\
\text { Abdullah alias Abdul Wakhid alias } \\
\text { Hamzah alias Arif Arhan }\end{array}$ & \\
\hline $\begin{array}{l}\text { Mahkamah Agung No. 2524 } \\
\text { K/PID.SUS/2010 }\end{array}$ & $\begin{array}{l}\text { Al Khelaiw Ali Abdullah A alias } \\
\text { Ali Saudi Arabia }\end{array}$ & \\
\hline
\end{tabular}

Sumber: Direktori putusan Mahkamah Agung.

Secara sistematis, peneliti melakukan pembacaan terhadap seluruh putusan tersebut, yang diikuti dengan pencarian frasa 'paspor', 'passport', 'imigrasi', dan 'luar negeri'. Frasa-frasa tersebut dianggap oleh peneliti sebagai cerminan dari relasi antara tindak pidana terorisme dengan fungsi keimigrasian. Berdasarkan penelusuran yang dilakukan, beberapa kasus yang dikategorikan menggambarkan hubungan tersebut adalah sebagai berikut. Dalam kasus dengan terpidana Cahya Fitriyanta, terungkap fakta bahwa ${ }^{19}$

Dari hasil bajak situs yang dilakukan sendiri oleh Terdakwa, telah mendapat uang sebesar Rp400.000.000,00 (empat ratus juta Rupiah), lalu diberikan kepada Jipo (anggota kelompok teroris) sebesar Rp150.000.000,00 (seratus lima puluh juta Rupiah) untuk membuat passport berjihad ke luar negeri. Jipo juga adalah anggota teroris yang ada saat latihan militer di Poso; Bahwa Terdakwa melakukan transfer uang sebesar Rp79.000.000,00 (tujuh puluh sembilan juta Rupiah) ke atas nama Erlangga dan juga di Bank Muamalat sebesar Rp50.000.000,00 (lima puluh juta Rupiah). Terdakwa juga memberikan uang kepada Naim yang juga anggota jaringan terorisme. Selain itu, Terdakwa juga kenal dan mempunyai hubungan dengan Heri koncoro yang menjadi pelaku tindak pidana terorisme; Bahwa Terdakwa mengumpulkan dana untuk kepentingan beberapa orang anggota teroris berjihad ke luar negeri [...].

Kasus tersebut menggambarkan bahwa di dalam tindak pidana terorisme mengandung aspek keimigrasian dalam konteks pembuatan paspor. Dalam hal ini, terdapat fenomena bahwa ada warga Negara Indonesia tertentu, yang juga diidentifikasi sebagai anggota kelompok teroris, yang akan mengajukan paspor dalam rangka berjihad ke luar negeri. Selanjutnya dalam kasus Al Khelaiw Ali Abdullah A, ditemukan fakta bahwa seorang warga negara asing juga dapat terlibat dalam kejahatan terorisme yang terjadi di wilayah Indonesia, dengan rincian-rincian. ${ }^{20}$ Pertama, bahwa Terdakwa datang ke Indonesia pada Nopember tahun 2008 dengan Visa Turis, dan dalam waktu singkat Terdakwa kenal dengan Saefudin Zuhri (Teroris) dan bergaul, menginap dan kemudian dicarikan rumah kontrakan oleh Saefudin Zuhri tersebut. Terdakwa juga kenal Dani Dwi Permana (bom Hotel Marriot) dan akrab; bahwa Terdakwa selama 1 (satu) bulan ini bergaul selalu dengan orang-orang yang kemudian dikenal sebagai Teroris.

\footnotetext{
${ }^{19}$ MARI Putusan No 1497/K/PIDSUS/2013, .

${ }^{20}$ MARI Putusan No 2524 K/PIDSUS/2010, .
} 
Kedua, pada Desember 2008 Terdakwa datang lagi ke Indonesia dengan disponsori oleh Saefudin Zuhri (almarhum/telah meninggal dunia akibat kontak senjata dengan Polri Densus Anti Terror di Jalan Semanggi I, Kelurahan Cempaka Putih, Ciputat Tangerang Selatan). Bahwa selama kunjungan Terdakwa yang kedua ini, tidak pernah terungkap apa sebenarnya maksud kedatangan Terdakwa ke Indonesia, yang jelas Terdakwa berada dalam lingkungan yang dikenal sebagai Teroris dan Terdakwa beberapa kali mengikuti pengajian dan bermalam di rumah Saefudin Zuhri di Kahuripan Parung. Terdakwa hidup di tengah kehidupan para Teroris dalam keseharian dengan mengikuti kegiatan yang ada, nampak adanya samenspel (kehidupan bersama yang akrab) antara mereka, sehingga ada kesengajaan Terdakwa member i bantuan keuangan kepada Saefud in Zuhr I sebagai otak pemboman Hotel J.W. Marriot dan Ritz Carlton).

Ketiga, bahwa Terdakwa ada kan uang sekitar Rp 50.000.000,- (lima puluh juta rupiah ) dengan alasan membuka usaha warnet dan dagang komputer bekas namun dalam kenyataannya, uang dari Terdakwa juga mengalir, Tanggal 06 Januari 2009 Rp 1.400.000,- (satu juta empat ratus ribu rupiah) ke Rekening BCA Saefudin Zuhri, Rp 500.000,- (lima ratus ribu rupiah) pada Saefudin Zuhri via Iwan, Rp 500.000,- (lima ratus ribu) pada Saefudin Zuhri via Amir Abdilah. April 2009 sebesar Rp 400.000,(empat ratus ribu rupiah) melalui Iwan Herdiansyah kepada Saefudin Zuhri.

Keempat, bahwa Terdakwa jauh-jauh dari Arab datang ke Indonesia dengan alasan akan menginvestasikan uangnya/berbisnis akan tetapi nyatanya modal bisnis Terdakwa hanya Rp 50.000.000,- (lima puluh juta rupiah) adalah alasan yang sangat ganjil, apalagi Terdakwa masuk ke Indonesia dengan menggunakan Visa Turis, yang seharusnya apabila benar ia akan menanamkan modal dengan berbisnis di Indonesia dari Arab Saudi tentu Terdakwa menggunakan Visa Bisnis.

Kelima, bahwa kedatangan Terdakwa ke Indonesia dengan sejumlah uang tertentu adalah tidak jelas untuk apa, tetapi faktanya Terdakwa hidup/berada di tengah-tengah manusia yang kita kenal kemudian sebagai Teroris yang disergap/ditembak mati oleh Densus 88, apalagi jelas ada uang yang beredar yang berasal dari Terdakwa.

Keenam, perbuatan Terdakwa memberi bantuan atau kemudahan terhadap pelaku tindak pidana Terorisme dengan memberikan atau meminjamkan uang dan menyalahgunakan Ijin Keimigrasian sebagaimana dakwaan Pertama dan Kedua telah terbukti dalam perbuatan Terdakwa.

Kasus Ali tersebut menggambarkan hubungan kejahatan terorisme dengan fungsi keimigrasian dalam aspek visa dan ijin tinggal. Hubungan ini bisa terjadi karena warga Negara Indonesia, yang diidentifikasi sebagai anggota teroris, menjadi sponsor kedatangan warga negara asing ke wilayah Indonesia. Terakhir, dalam kasus Taufik Bin Marzuki, hubungan antara kejahatan terorisme dengan aspek keimigrasian melibatkan spektrum yang lebih luas yakni pemalsuan identitas, sebagaimana tergambar dalam fakta persidangan berikut ${ }^{21}$

21 MARI Putusan No 167 PK/PIDSUS/2013, . 
Kemudian setelah melarikan diri pada tanggal 12 Mei 2010 Terdakwa dengan bantuan dari Idris Achmad dibuatkan KTP dengan nama Sulaiman Bin Tarmizi sebagai penduduk desa Geulumpang Kabupaten Aceh Utara, dan sekitar sebulan kemudian KTP dimaksud sudah selesai, kemudian Terdakwa pada tanggal 4 Juni 2010 pergi ke Lhokseumawe untuk membuat pasport di kantor Imigrasi Lhok Seumawe berdasarkan KTP an. Sulaiman Bin Tarmizi tersebut dan setelah mendapatkan passport an. Sulaiman Bin tarmizi tersebut Terdakwa pergi ke Malaysia melalui pelabuhan Tanjung Balai Asahan dengan menumpang kapal Fery dengan tujuan Malaysia, Terdakwa sempat tinggal di Malaysia kurang lebih 5 bulan hingga akhirnya ditangkap oleh Polisi Diraja Malaysia dan diserahkan kepada Kepolisian Negara Republik Indonesia pada tanggal 27 Oktober 2010 bertempat di Bandara Sukarno Hatta.

Kasus tersebut juga mengindikasikan bahwa paspor dengan yang dibuat atas dasar identitas palsu menyebabkan seorang warga Negara Indonesia yang merupakan anggota kelompok terorisme secara leluasa bepergian ke luar negeri dengan berbagai motif. Ketiga kasus tersebut setidaknya menggambarkan bahwa tindak pidana terorisme dapat melibatkan beberapa aspek di dalam fungsi keimigrasian, yakni pembuatan paspor, pengawasan di perbatasan, pengawasan orang asing, dan penerbitan visa dan ijin tinggal. Secara normatif di dalam UU Keimigrasian, frasa 'terorisme' dicantumkan sebagai penjelasan dari ketentuan yang mengatur tentang penolakan terhadap masuknya orang asing ke Indonesia atas dasar keterlibatan orang asing tersebut dalam kejahatan internasional dan tindak pidana transnasional yang terorganisasi. ${ }^{22}$ Dengan demikian, walaupun pelaksana fungsi keimigrasian tidak mengemban mandat secara langsung secara normatif dalam UU Terorisme, berdasarkan tinjauan kasus-kasus yang ada, Direktorat Jenderal Imigrasi tetap memiliki peran yang signifikan dalam mencegah dan memberantas tindak pidana terorisme. $^{23}$

\section{PERAN IMIGRASI DALAM PENCEGAHAN TINDAK PIDANA TERORISME}

Beranjak dari tinjauan atas kasus-kasus tindak pidana terorisme dan hubungannya dengan fungsi keimigrasian, kajian ini selanjutnya mengelaborasi peran imigrasi dalam mencegah tindak pidana terorisme ke dalam dua bagian, yakni pemeriksaan perbatasan dan entry permit, serta praktik koordinasi pelaksana fungsi keimigrasian dengan lembaga lain. Penjabaran berikut diperoleh peneliti dari pengumpulan data primer melalui wawancara kepada pejabat Imigrasi yang relevan, khususnya yang beraktivitas di

22 Pasal 13 huruf (g) dan Penjelasan UU 6/2011 tentang Keimigrasian, supra note 3.

23 W.S Deshinta, Fungsi Pengawasan Keimigrasian dalam Pengendalian Radikalisme Pasca Penerapan Kebijakan Bebas Visa Kunjungan, (Semarang: Universitas Negeri Semarang, 2017) 
Kantor Imigrasi Khusus Kelas I Bandara Soekarno-Hatta, serta beberapa data sekunder yang relevan. Hasil pengumpulan data tersebut dijabarkan sebagai berikut.

\section{B. Pemeriksaan Perbatasan dan Entry Permit}

Dalam kaitannya dengan kejahatan transnasional, termasuk tindak pidana terorisme, Imigrasi telah melakukan koordinasi dan kolaborasi dengan instansi-instansi pemerintah lainnya, khususnya aparat penegak hukum. ${ }^{24}$ Umumnya, koordinasi yang dijalankan berdasarkan sistem ialah melalui permintaan pencegahan dan penangkalan (CEKAL) ke pihak Imigrasi. Selain CEKAL, koordinasi kesisteman juga dilakukan melalui penyerahan nama individu yang termasuk di dalam daftar pencarian orang (DPO) kepolisian. Dua mekanisme tersebut, baik CEKAL dan DPO, dapat diakses oleh pihak office Imigrasi di bandara, untuk selanjutnya disampaikan kepada counter Imigrasi sebagai pelaksana lapangan yang menghadapi orang/penumpang secara langsung.

Informasi tersebut dengan demikian sejalan dengan dasar hukum di dalam PP 31/2013 yang mengatur. Pertama, menteri berwenang dan bertanggung jawab melakukan Pencegahan yang menyangkut bidang Keimigrasian. Kedua, menteri melaksanakan Pencegahan berdasarkan hasil pengawasan Keimigrasian dan keputusan Tindakan Administratif Keimigrasian; Keputusan Menteri Keuangan dan Jaksa Agung sesuai dengan bidang tugas masing-masing dan ketentuan peraturan perundang-undangan; permintaan Kepala Kepolisian Negara Republik Indonesia sesuai dengan ketentuan peraturan perundang-undangan; perintah Ketua Komisi Pemberantasan Korupsi sesuai dengan ketentuan peraturan perundang-undangan; permintaan Kepala Badan Narkotika Nasional sesuai dengan ketentuan peraturan perundang-undangan; dan/atau keputusan, perintah, atau permintaan pimpinan kementerian/lembaga lain yang berdasarkan undang-undang memiliki kewenangan Pencegahan. ${ }^{25}$

Di luar mekanisme kesisteman tersebut, dalam konteks penindakan terduga teroris, koordinasi penyampaian data juga dilakukan oleh pihak Kepolisian, Badan Intelijen Negara, Badan Nasional Pemberantasan Terorisme, maupun Interpol kepada pihak Imigrasi. Penyampaian data tersebut dilakukan dengan memanfaatkan teknologi komunikasi saat ini, baik melalui panggilan telepon, hingga aplikasi whatsapp. Menurut narasumber, data melalui jalur informal tersebut dapat secara efektif berkontribusi terhadap penanganan tindak pidana terorisme secara lebih cepat, khususnya dalam mengidentifikasi keluar/masuknya pihak-pihak yang diduga teroris di wilayah Indonesia.

Dalam konteks yang demikian, jalur informal tersebut dikategorikan sebagai keadaan mendesak, sebagaimana diatur di dalam Pasal 228 PP 31/2013, yang mengatur bahwa ayat (1) dalam keadaan mendesak pejabat yang berwenang sebagaimana

24 Wawancara dengan Kepala Kantor Imigrasi Kelas I Khusus Bandara Soekarno-Hatta (September, 2018).

25 Pasal 226 Peraturan Pemerintah Nomor 31 Tahun 2013 tentang Peraturan Pelaksanaan Undang-Undang Nomor 6 Tahun 2011 tentang Keimigrasian [Peraturan Pemerintah Nomor 31 Tahun 2013 tentang Peraturan Pelaksanaan Undang-Undang Nomor 6 Tahun 2011 tentang Keimigrasian]. 
dimaksud dalam Pasal 226 ayat (2) dapat meminta secara langsung kepada Pejabat Imigrasi tertentu untuk melakukan Pencegahan. Ayat (2) Pejabat Imigrasi tertentu sebagaimana dimaksud pada ayat (1) adalah Pejabat Imigrasi pada Tempat Pemeriksaan Imigrasi atau unit pelaksana teknis yang membawahi Tempat Pemeriksaan Imigrasi. Ayat (3) Pejabat Imigrasi setelah menerima permintaan secara langsung dari pejabat yang berwenang sebagaimana dimaksud pada ayat (1) segera melaksanakan Pencegahan. Ayat (4) dalam hal pejabat yang berwenang sebagaimana dimaksud dalam Pasal 226 ayat (2) tidak ada, keputusan, permintaan, atau perintah Pencegahan dapat dilakukan oleh pejabat yang ditunjuk. Ayat (5) Pejabat yang berwenang sebagaimana dimaksud pada ayat (1) dan pejabat yang ditunjuk sebagaimana dimaksud pada ayat (4) wajib menyampaikan keputusan tertulis kepada Menteri dalam waktu paling lama 20 (dua puluh) hari terhitung sejak permintaan secara langsung disampaikan. Ayat (6) apabila dalam batas waktu sebagaimana dimaksud pada ayat (5) tidak ada keputusan tertulis dari pejabat yang berwenang atau pejabat yang ditunjuk, Pencegahan berakhir demi hukum.

Secara lebih makro, narasumber beranggapan bahwa pencegahan kejahatan terorisme sesungguhnya dapat dilakukan semenjak tahap pembuatan/ penerbitan paspor. ${ }^{26}$ Dalam hal ini, dengan mendasarkan pada asas praduga tak bersalah, maka setiap warga negara Indonesia dapat diberikan paspor selama tidak terdapat informasi tertentu dari pihak aparat penegak hukum, seperti keterlibatan seseorang dalam organisasi teroris. Namun demikian pada tataran praktis, menurut narasumber, selama ini sinkronisasi data belum tercipta antar instansi seperti BIN, BAIS, Interpol, Densus 88, maupun Imigrasi sendiri. ${ }^{27}$ Sinkronisasi data, khususnya data intelijen, menjadi penting dalam rangka upaya cegah dini dari terjadinya kejahatan terorisme di Indonesia. Dari perspektif keimigrasian, upaya cegah dini dapat dilakukan melalui penguatan fungsi screening pada saat wawancara pembuatan paspor. Dengan sinkronisasi data yang mapan, diharapkan petugas Imigrasi akan memperoleh basis bukti yang sahih dalam memutuskan terbit atau tidaknya paspor bagi seseorang.

\section{Koordinasi dan Kolaborasi Ditjen Imigrasi dengan Instansi Lain}

Sejak tahun 2016, Direktorat Jenderal Imigrasi telah melakukan kerja sama dengan NCB-Interpol melalui penggunaan aplikasi I-24/7. Aplikasi ini merupakan produk dari Interpol yang dapat digunakan untuk mendeteksi data dokumen, semisal paspor, yang hilang atau dicuri (lost or stolen document). Dalam perkembangannya pada 2018 (26/1), Ditjen Imigrasi dan NCB-Interpol telah menandatangani standar operasional prosedur (SOP) tentang penanganan hits atau alert pada sistem Interpol 24/7 yang terintegrasi dengan sistem Border Control Management (BCM). Adapun tujuan dari penandatanganan SOP ini ialah untuk mengatur mekanisme penanganan hits atau alert "dalam rangka melakukan deteksi dini buronan dan pelaku kejahatan transnasional di lintas batas, baik melalui data dokumen perjalanan yang hilang atau dicuri (stolen/lost travel document

26 Wawancara dengan Kepala Kantor Imigrasi Kelas I Khusus Bandara Soekarno-Hatta, Ibid.

27 Ibid. 
- SLTD) maupun melalui data nominal (data Interpol Notices dan Diffusion)." ${ }^{28}$ (NCBInterpol Indonesia, 2018) Secara bertahap, integrasi sistem Interpol I24/7 dengan BCM Imigrasi sudah diterapkan di Bandara Soekarno-Hatta dan Ngurah Rai, untuk kemudian diharapkan dapat dioperasionalkan di seluruh bandara dan pelabuhan laut di Indonesia pada 2020. (NCB-Interpol Indonesia, 2018)

Secara normatif berdasarkan Peraturan Kepala Kepolisian No. 5 Tahun 2011 tentang Penggunaan Jaringan Interpol (I-24/7) dan Jaringan ASEANAPOL (e-ADS) di Indonesia, I-24/7 didefinisikan sebagai "jaringan komunikasi global INTERPOL (Interpol Global Police Communications System) yang bekerja selama 24 (dua puluh empat) jam sehari dan 7 (tujuh) hari seminggu, yang digunakan sebagai sarana pertukaran informasi antara negara anggota ICPO-Interpol yang cepat, tepat, akurat dan aman." Dalam konteks keimigrasian, kolaborasi ini sangat erat kaitannya dengan intelijen keimigrasian. Secara normatif, Intelijen Keimigrasian merupakan "kegiatan penyelidikan Keimigrasian dan pengamanan Keimigrasian dalam rangka proses penyajian informasi melalui analisis guna menetapkan perkiraan keadaan Keimigrasian yang dihadapi atau yang akan dihadapi." Dengan begitu, dalam kaitannya dengan koordinasi dan kolaborasi antar lembaga, peran Interpol menjadi signifikan melalui program The Integrated Border Management Task Force (IBMTF) yang dapat mendukung aparatur penegak hukum dalam berkoordinasi dan meningkatkan kemampuan untuk data-sharing.

Dalam tataran praktis, beberapa operasi pengamanan perbatasan telah dilakukan oleh Indonesia bersama-sama dengan Malaysia dan Filipina untuk mengamankan wilayah perbatasan yang diduga menjadi area pelintasan kejahatan transnasional terorganisasi, termasuk terorisme. Operasi bersama ini dijalankan secara insidentil, dan didukung sepenuhnya oleh Interpol.

\section{MODEL KONTROL IMIGRASI DALAM PENCEGAHAN T INDAK PIDANA TERORISME}

Berdasarkan analisis data yang ada, kajian ini menemukan fakta bahwa model kontrol keimigrasian dalam pencegahan tindak pidana terorisme dibangun berdasarkan tiga unsur utama dalam pelaksanaan tugas keimigrasian, yang meliputi: intelijen keimigrasian, pengawasan keimigrasian, dan pemeriksaan di perbatasan. ${ }^{29}$ Merujuk pada praktik yang ada selama ini, pencegahan tindak pidana terorisme oleh pihak keimigrasian berjalan secara singuler, dalam pengertian bahwa masing-masing elemen keimigrasian bekerja berdasarkan proses kerjanya secara terpisah. Proses-proses yang

\footnotetext{
28 NCB-Interpol, "Penandatanganan SOP Polri-Ditjen Imigrasi tentang Penanganan Hits atau Alert pada Sistem Interpol I-24/7 yang Berintegrasi dengan Sistem Border Control Management (BCM) Imigrasi", diakses 28/3/2019 pada laman (https:/interpol.go.id/en/news/776-penandatanganan-sop-polri-ditjen-imigrasi-tentang penanganan-hits-atau-alert-pada-sistem-interpol-i-247-yang-berintegrasi-dengan-sistem-bordercontrol-management-bcm-imigras)

29 A Nowrasteh, Policy Analysis: Terrorism and Immigration (CATO Institute, 2016).
} 
berjalan singuler ini menghasilkan produk atau keluarannya masing-masing, tanpa adanya keterpaduan di antara mereka.

Secara konseptual dan normatif, tiga elemen tersebut pada prinsipnya merupakan sebuah siklus yang saling terkait antara satu dengan yang lain. Dengan demikian, model kontrol imigrasi dalam pencegahan tindak pidana terorisme seharusnya bersifat sirkuler, dalam pengertian bahwa ketimbang hubungan kerja antar elemen yang mencerminkan alur yang singuler atau hulu ke hilir, maka sebaiknya diarahkan kepada bentuk rantai kerja yang saling terkait. Adapun untuk menggambarkan model sirkuler tersebut, perlu kiranya meninjau beberapa aspek teknis terkait fungsi keimigrasian yang dapat berkontribusi dalam pencegahan tindak pidana terorisme.

\section{A. Optimalisasi Pengawasan Keimigrasian}

Analisis optimalisasi pengawasan keimigrasian akan dipilah berdasarkan klasifikasi pengawasan berdasarkan subjeknya, yakni pengawasan keimigrasian terhadap warga negara Indonesia dan terhadap warga negara asing. (Pasal 66 UU 6/2011) Untuk klasifikasi yang pertama, yakni pengawasan keimigrasian terhadap warga negara Indonesia, secara teknis Pasal 172 ayat (3) PP No. 31 Tahun 2013 mengatur bahwa "Pengawasan Keimigrasian terhadap warga negara Indonesia dilakukan pada saat permohonan Dokumen Perjalanan Republik Indonesia; keluar atau masuk Wilayah Indonesia; dan berada di luar Wilayah Indonesia."

Adapun berdasarkan objeknya, pengawasan tersebut dibagi menjadi dua jenis, yakni pengawasan administratif dan pengawasan lapangan. Terkait hal ini, Pasal 175 PP 31/2013 mengatur bahwa "Pengawasan administratif terhadap warga negara Indonesia dilakukan dengan pertama, pengumpulan, pengolahan, serta penyajian data dan informasi mengenai pelayanan Keimigrasian kepada warga negara Indonesia; pengajuan permohonan Dokumen Perjalanan Republik Indonesia yang dilakukan oleh warga negara Indonesia; dan lalu lintas warga negara Indonesia yang masuk atau keluar Wilayah Indonesia. Kedua, penyusunan daftar nama warga negara Indonesia yang dikenai Pencegahan keluar Wilayah Indonesia; dan pengambilan foto dan sidik jari.

Sedangkan pengawasan lapangan terhadap warga negara Indonesia dapat dilakukan dengan (Pasal 176) yakni mencari dan mendapatkan keterangan mengenai keberadaan warga negara Indonesia yang berada di luar Wilayah Indonesia; melakukan wawancara pada saat memohon Dokumen Perjalanan Republik Indonesia; atau melakukan koordinasi dengan pemerintah negara setempat melalui Kepala Perwakilan Republik Indonesia untuk memantau keberadaan warga negara Indonesia di luar Wilayah Indonesia.

Berdasarkan aturan tersebut, unsur pengawasan administratif yang krusial ialah pada pengumpulan, pengolahan, serta penyajian data dan informasi. ${ }^{30}$ Dalam hal pengajuan Dokumen Perjalanan Republik Indonesia, sistem penerbitan paspor, selain

30 Secara lebih teknis, Permenkumham No. 4 Tahun 2017 tentang Tata Cara Pengawasan Keimigrasian mengatur bahwa pengawasan administratif dilakukan melalui pemeriksaan dan penelitian berkas atau dokumen secara manual dan/atau melalui Simkim. 
mengedepankan pelayanan prima kepada masyarakat, juga wajib memperhatikan unsur keamanan. Dalam rangka meningkatkan kewaspadaan, pihak Direktorat Jenderal Imigrasi telah menerbitkan dua surat edaran, yakni: Surat Edaran Direktur Jenderal Imigrasi Nomor: IMI-1562.GR.01.01 Tahun 2014 tentang Peningkatan Kewaspadaan dalam Penerbitan Paspor, dan Surat Direktur Jenderal Imigrasi Nomor: IMI.5GR.04.02.1273 tentang Kewaspadaan terhadap Anggota / Simpatisan Kelompok Militan Negara Islam Irak dan Suriah (ISIS). Surat Edaran Direktur Jenderal Imigrasi tersebut merupakan wujud langkah preventif Ditjen Imigrasi dalam rangka mencegah keterlibatan warga negara Indonesia dalam kelompok militan ISIS di luar negeri. Dalam hal ini, Direktorat Jenderal Imigrasi menginstruksikan kepada seluruh Kepala Kantor Imigrasi di Indonesia agar dalam proses penerbitan paspor untuk memperhatikan unsur keamanan dengan melakukan penelitian berkas secara cermat dan wawancara secara teliti. Terhadap adanya indikasi WNI yang akan pergi keluar negeri dalam rangka bergabung dengan kelompok ISIS, setiap Pejabat Imigrasi yang bertugas di Tempat Pemeriksaan Imigrasi seluruh Indonesia diminta agar mengambil tindakan tegas untuk menunda keberangkatan WNI tersebut untuk dilakukan pemeriksaan lebih lanjut.

Selain itu, beranjak dari kasus hukum yang terjadi, pengawasan keimigrasian perlu ditekankan dalam konteks warga negara Indonesia yang menjadi penjamin keberadaan orang asing di Indonesia. Secara normatif, pengawasan lapangan terhadap warga negara Indonesia tersebut dilakukan "jika terdapat keraguan mengenai keterangan, keabsahan dokumen persyaratan, identitas dan/atau kesanggupan sebagai penjamin." (Pasal 28 Permenkumham 4/2017) Secara teknis, mekanisme pengawasan diatur sebagai berikut. Pertama, Kepala Kantor Imigrasi memerintahkan Pejabat Imigrasi untuk melakukan pengawasan lapangan. Kedua, Pejabat Imigrasi melakukan rapat persiapan rencana kegiatan. Ketiga, pelaksanaan pengawasan lapangan dilakukan melalui pengumpulan data dan informasi dengan cara mendatangi: 1. Tempat tinggal pemohon, 2. Kepala desa/kelurahan tempat tinggal pemohon; dan/atau 3. Instansi yang menerbitkan dokumen domisili dan identitas diri pemohon. Keempat, Pejabat Imigrasi yang ditunjuk menyusun laporan dan evaluasi hasil pengawasan lapangan.

Mekanisme ini mencerminkan bahwa baik pengawasan administratif maupun lapangan cenderung difokuskan pada persoalan keabsahan dokumen seorang warga negara Indonesia. Merujuk pada deskripsi tentang fungsi intelijen keimigrasian sebelumnya, dapat dipahami bahwa profiling dan data mining seharusnya menjadi unsur pembentuk pengawasan secara administratif. ${ }^{31}$ Sebagai konsekuensi, hasil dari aktivitas profiling dan data mining intelijen harus terus bekerja secara selaras pada saat seorang warga negara Indonesia mengajukan permohonan Dokumen Perjalanan Republik Indonesia, keluar atau masuk Wilayah Indonesia, dan ketika sedang berada di luar

31 Karen C Tumlin, "Suspect First: How Terrorism Policy Is Reshaping Immigration Policy" 92:4 Calif Law Rev 1173. 
Wilayah Indonesia. Lebih jauh, koordinasi antar lembaga ataupun kementerian demi mencegah terbitnya paspor bagi terduga teroris sangat penting. ${ }^{32}$

Sedangkan dari sisi pengawasan keimigrasian terhadap orang asing, Pasal 172 ayat (4) PP No. 31 Tahun 2013 mengatur bahwa pengawasan tersebut dilakukan pada saat permohonan Visa, masuk atau keluar Wilayah Indonesia, pemberian Izin Tinggal; dan berada dan melakukan kegiatan di Wilayah Indonesia. Dalam rangka pengawasan terhadap warga negara asing, berdasarkan kasus tindak pidana terorisme yang terjadi, tahapan permohonan visa menjadi krusial. Permenkumham No. 24 Tahun 2016 tentang Prosedur Teknis Permohonan dan Pemberian Visa Kunjungan dan Visa Tinggal Terbatas mengatur bahwa pemberian Visa Kunjungan yang diajukan oleh orang asing dilaksanakan setelah melalui, salah satunya, "penelitian latar belakang orang asing melalui media elektronik atau media lainnya serta arsip layanan keimigrasian sebagai pertimbangan risiko akan dampak kedatangan orang asing ke Indonesia terhadap keamanan, ketertiban, ekonomi, sosial, politik, dan budaya Indonesia." (vide Pasal 17, 18, 19, dan 20) Dalam konteks pencegahan dugaan pelaku tindak pidana terorisme, tentu tahapan tersebut tidak akan mampu secara komprehensif menjadi dasar untuk keputusan pemberitaan visa. Untuk itu, menjadi logis untuk mengintegrasikan hasil profiling dan data mining intelijen keimigrasian di dalam proses ini. Hasil profiling dan data mining intelijen seharusnya sudah tersedia pada saat seorang warga negara asing mengajukan permohonan visa. Logika yang sama pada prinsipnya berlaku mutatis mutandis pada tahap masuk atau keluar wilayah Indonesia, mengajukan Izin Tinggal, dan ketika sedang berada dan melakukan kegiatan di Wilayah Indonesia.

\section{B. Intelijen Keimigrasian: Profiling dan Data Mining}

Salah satu aspek penting dalam optimalisasi pengawasan keimigrasian yang telah dibahas sebelumnya ialah efektivitas data sharing. Dalam kaitannya dengan hal ini, praktik di negara lain menggambarkan beberapa tantangan yang ditemukan dalam rangka mencegah dan menangani kejahatan transnasional, dalam hal ini terorisme, yang mencakup pertama, heterogenitas data. Dalam hal ini data yang dikumpulkan oleh instansi-instansi yang berbeda memiliki perbedaan struktural dan semantik; Kedua, heterogenitas bahasa. Perbedaan pencantuman bahasa di dalam dokumen tidak dapat digunakan oleh instansi yang berada di negara berbeda; ketiga, heterogenitas orang dan lingkungan kerja. Instansi-instansi pemerintah memiliki tingkat kemapanan pemakaian teknologi informasi yang berbeda-beda; keempat, heterogenitas kebijakan, regulasi, batasan dan aturan keamanan masing-masing instansi; kelima kesulitan dalam komunikasi dan koordinasi antar instansi; dan keenam heterogenitas dalam platform

32 H Djalal, "Menentukan Batas Negara Guna Meningkatkan Pengawasan, Penegakan Hukum dan Kedaulatan NKRI" 3:2 J Pertahanan Dan Bela Negara 15. 
komputansi, seperti perangkat keras dan lunak, sistem manajemen data, dan sistem aplikasi dalam menjalankan fungsinya. ${ }^{33}$

Dalam konteks keimigrasian di Indonesia, berdasarkan Pasal 74 Ayat 2 UU Keimigrasian, Intelijen Keimigrasian mengemban wewenang untuk mendapatkan keterangan dari masyarakat atau instansi pemerintah; mendatangi tempat atau bangunan yang diduga dapat ditemukan bahan keterangan mengenai keberadaan dan kegiatan Orang Asing; melakukan operasi Intelijen Keimigrasian; atau melakukan pengamanan terhadap data dan informasi Keimigrasian serta pengamanan pelaksanaan tugas Keimigrasian.

Secara lebih spesifik, yang dimaksud dengan "penyelidikan keimigrasian" adalah kegiatan atau tindakan Pejabat Imigrasi untuk mencari dan menemukan suatu peristiwa yang diduga sebagai tindak pidana keimigrasian." Sedangkan yang dimaksud dengan "operasi Intelijen Keimigrasian" adalah "kegiatan yang dilakukan berdasarkan suatu rencana untuk mencapai tujuan khusus serta ditetapkan dan dilaksanakan atas perintah Pejabat Imigrasi yang berwenang." Secara lebih teknis, berdasarkan Peraturan Menteri Hukum dan Hak Asasi Manusia Nomor 30 Tahun 2016 tentang Intelijen Keimigrasian, fungsi tersebut meliputi dua aspek, yakni penyelidikan Intelijen Keimigrasian dan pengamanan Intelijen Keimigrasian. Adapun penyelidikan Intelijen Keimigrasian dilaksanakan untuk mencari, mendapatkan, memperoleh, dan mengolah data/atau informasi yang berkaitan dengan objek sasaran di bidang Keimigrasian. Sedangkan pengamanan keimigrasian dilaksanakan dengan tujuan untuk deteksi secara dini dan upaya pencegahan terhadap ancaman, tantangan, hambatan, dan gangguan terlaksananya fungsi keimigrasian.

Berdasarkan Pasal 19 Permenkumham 30/2016, “setiap pelaksanaan operasi Intelijen Keimigrasian harus dituangkan dalam bentuk produk hasil Operasi Intelijen Kemigrasian." Adapun produk tersebut disusun dalam bentuk laporan dan disampaikan secara berjenjang kepada Direktur Jenderal. (Psl 21 jo. 22) Pada titik ini, guna mewujudkan model kontrol keimigrasian yang bersifat sirkuler, seharusnya produk hasil operasi intelijen keimigrasian dibagikan kepada pelaksana fungsi pengawasan dan fungsi pemeriksaan di perbatasan. Tidak hanya berhenti pada titik tersebut, pihak intelijen keimigrasian juga sepatutnya menyusun database orang-orang yang patut diduga berafiliasi atau bergabung dengan kelompok teroris luar negeri. Database daftar terduga teroris tersebut dapat menjadi produk intelijen setelah proses pengelolaan data intelijen keimigrasian dalam bentuk kalkulasi penilaian risiko (risk assessment calculation). Merujuk pada praktik Department of Homeland Security di Amerika Serikat misalnya, kalkulasi risiko terorisme merupakan hasil dari persamaan ancaman dikalikan kerentanan dikalikan kekritisan. ${ }^{34}$

33 SE Su, "Transnational Information Sharing, Event Notification, Rule Enforcement and Process Coordination" (2005) 1:2 Int J Electron Gov Res 1, hlm. 2.

34 Joel Leson, Assessing and Managing the Terrorism Threat, U.S Department of Justice Bureau of Justice Assistance, Washington: September 2005, hlm. 9. 
Mengingat luasnya dimensi dan institusionalisasi kalkulasi risiko terorisme tersebut, intelijen keimigrasian akan memiliki posisi yang strategis dalam mendukung penilaian ancaman (threat assessment). Dalam penilaian ancaman tersebut, data intelijen keimigrasian dapat diarahkan pada beberapa poin berikut yakni, Type of adversary: Terrorist, activist, employee, other; Category of adversary: Foreign or domestic, terrorist or criminal, insider and/or outsider of the organization; Objective of each type of adversary: Theft, sabotage, mass destruction (maximum casualties), sociopolitical statement, other; Number of adversaries expected for each category: Individual suicide bomber, grouping or "cells" of operatives/terrorists, gangs, other; Target selected by adversaries: Critical infrastructure, governmental buildings, national monuments, other; Type of planning activities required to accomplish the objective: Longterm "casing," photography, monitoring police and security patrol patterns, other; Most likely or "worstcase" time an adversary could attack: When facility/location is fully staffed, at rush hour, at night, other; Range of adversary tactics: Stealth, force, deceit, combination, other; dan Capabilities of adversary: Knowledge, motivation, skills, weapons and tools. ${ }^{35}$

Threat assessment yang diperoleh dari pengelolaan data intelijen tersebut diharapkan dapat mendukung upaya profiling terhadap individu-individu yang diduga berpotensi melakukan kejahatan terorisme di Indonesia. Namun demikian, dalam praktik di beberapa negara, pengelolaan data intelijen keimigrasian tersebut menemukan tantangan terkait pelindungan hak asasi manusia. Relasi tersebut ditemukan dalam konteks praktik surveilans melalui penyadapan dalam rangka pelaksanaan fungsi intelijen yang berpotensi melanggar hak atas privasi. Surveilans, merupakan salah satu bentuk intrusi terhadap kehidupan privasi seseorang yang menjadi bagian dari hak asasi manusia. ${ }^{36}$ Secara sederhana, kegiatan surveilans mencakup tindakan pengamatan (observation) dan pengumpulan informasi (information gathering). ${ }^{37}$ Dalam perkembangannya, bentuk surveilans dilakukan melalui bentuk lain seperti penggalian data (data mining) dan menyimpan data (data retention). Data mining ialah teknologi untuk mendapatkan informasi berharga yang berasal dari data-data umum tertentu (low value inputs). Sedangkan data retention adalah mekanisme penyimpanan data dalam jangka waktu tertentu yang dapat digunakan sewaktu-waktu (recalling). ${ }^{38}$

Perkembangan pelindungan atas privasi berimplikasi terhadap standar hak asasi manusia dalam praktik surveilans. Sebagaimana tercantum dalam Pasal 17 Kovenan Internasional Hak-hak Sipil dan Politik. Ayat (1) No one shall be subjected to arbitrary or unlawful interference with his privacy, family, home, or correspondence, nor to unlawful attacks on his

35 Ibid, hlm. 6.

36 Wahyudi Djafar dan Miftah Fadhli, Surveilans dan Hak Asasi Manusia: Rekomendasi Pengintegrasian Standar Hak Asasi Manusia dalam Pembentukan Kebijakan Surveilans di Indonesia, Lembaga Studi dan Advokasi Masyarakat (ELSAM) dan Privacy International, Jakarta: 2015, hlm. 9

37 Ibid, hlm. 4

38 Whitefield Diffie dan Sudan Landau, Privacy on the Line: The Politics of Wiretapping and Encryption, The MIT Press, Cambridge: 2007, hlm. 292 
honour and reputation. Ayat (2) Everyone has the right to the protection of law against such interference or attacks.

Definisi dari 'arbitrary or unlawful interference' dalam pasal tersebut mengisyaratkan bahwa pelindungan terhadap hak atas privasi bukan merupakan pelindungan yang bersifat absolut, melainkan dapat dikecualikan, dengan pelaksanaan yang diatur oleh undang-undang. ${ }^{39}$ Adapun pengaturan oleh undang-undang tersebut tidak hanya mengatur tentang tata cara intrusi terhadap hak atas privasi, melainkan juga segala bentuk pengaksesan dan penyimpanan informasi pribadi dalam sistem komputer, penyimpanan data maupun peralatan lain, baik yang dilakukan oleh lembaga publik maupun privat.

Dewan HAM PBB melalui Resolusi 69/166 menyerukan kepada negara anggota untuk mementingkan pelindungan terhadap privasi dalam menghadapi perkembangan teknologi dan informasi dewasa ini. Lebih spesifik, terdapat dua hal mengenai praktik surveilans: pertama, negara wajib meninjau segala prosedur, praktik dan legislasi yang berkaitan dengan surveilans terhadap komunikasi, penyadapan, dan segala bentuk perolehan data-data privasi. Kedua, membentuk atau menegakkan peradilan yang imparsial, setara, efektif dan independen, mekanisme pengawasan nasional baik melalui peraturan administratif maupun yang ditetapkan oleh parlemen untuk memastikan transparansi yang memadai, dan akuntabilitas negara atas praktik surveilans komunikasi yang dilakukannya.

Dalam konteks Indonesia, hal yang patut menjadi perhatian adalah tumpang tindihnya regulasi yang mengatur tentang kewenangan penyadapan sebagai salah satu bentuk surveilans itu sendiri. Terdapat sedikitnya duapuluh peraturan perundangundangan berbeda yang memuat materi surveilans; mulai dari Undang-Undang, Peraturan Pemerintah, Peraturan Menteri, hingga Peraturan Kapolri. ${ }^{40}$ Tidak adanya keseragaman model pengaturan mengenai mekanisme surveilans ini menimbulkan adanya overlapping peraturan dan ketidakpastian hukum yang berpotensi menghadirkan pelanggaran terhadap hak atas privasi.

Beranjak dari ketentuan Pasal 9 huruf e jo. Pasal 14 UU Intelijen Negara, Penyelenggara Intelijen Negara salah satunya adalah intelijen kementerian/lembaga pemerintah non-kementerian. Posisi Intelijen Keimigrasian diperkuat melalui Pasal 5 Permenkumham 30/2016 yang membuka ruang bagi Pejabat Imigrasi untuk mencari, mendapatkan, memperoleh, mengumpulkan, dan mengolah data dan/atau informasi yang berkaitan dengan objek sasaran keimigrasian dalam rangka penyelidikan intelijen keimigrasian. Selanjutnya dalam Pasal 9, penyelidikan intelijen keimigrasian secara tertutup dapat dilaksanakan salah satunya melalui penyadapan. Fungsi ini, tentu berimplikasi terhadap tanggungjawab Ditjen Imigrasi untuk menyelenggarakan praktik surveilans yang tetap menghormati hak asasi manusia.

39 Komentar Umum No. 16 Pasal 17 KIHSP, Par. 3

40 Wahyudi Djafar dan Miftah Fadhli, Surveilans dan Hak Asasi Manusia: Rekomendasi Pengintegrasian Standar Hak Asasi Manusia dalam Pembentukan Kebijakan Surveilans di Indonesia, Lembaga Studi dan Advokasi Masyarakat (ELSAM) dan Privacy International, Jakarta: 2015, hlm. 17 
Sebagaimana tercantum dalam Pasal 29 ayat (2) Permenkumham 30/2016, dalam melaksanakan fungsi intelijen keimigrasian, diperlukan sarana dan prasarana yang salah satunya dalam bentuk database dalam Sistem Informasi Manajemen Keimigrasian. Database tersebut, tentunya akan memuat informasi sensitif mengenai produk operasi intelijen keimigrasian, sehingga meningkatkan urgensi adanya prosedur khusus terkait pengamanan data. Terlebih, konsep database sangat berkaitan dengan penyimpanan data (data retention) yang memiliki jangka waktu tertentu. Kebocoran atas data tersebut sebelum jangka waktu yang ditentukan, tentu merupakan pelanggaran terhadap hak atas privasi pemilik data.

Lebih jauh dalam lensa hak asasi manusia, proses pengumpulan data juga dapat berimplikasi pada bentuk profiling yang mengarah pada bentuk stereotip dan diskriminasi kepada kelompok masyarakat tertentu atas basis ras, etnis dan suku bangsa, ataupun agama. ${ }^{41}$ Stereotip ini pada derajat tertentu akan berujung pada stigmatisasi dan marjinalisasi kepada kelompok yang diduga teroris. ${ }^{42}$ Profiling berbasis ras di Amerika Serikat pasca serangan teroris 9/11 misalnya, berimplikasi terhadap penangkapan warga keturunan Arab dan Muslim yang diduga terkait dengan kegiatan terorisme. ${ }^{43}$ Salah satu kasus yang menarik ialah kasus Jose Padilla, warga Muslim Amerika Serikat yang ditangkap di Bandara O'hare, Chicago, setelah kepulangannya dari Pakistan pada 2002. Padilla dinyatakan sebagai 'musuh kombatan' dan ditahan secara militer karena diduga terlibat rencana pengeboman oleh Al-Qaeda. ${ }^{44}$ Schildkraut menganalisis hasil polling yang dilakukan pasca serangan teror 9/1l, yakni 31\% masyarakat Amerika Serikat setuju atas "penahanan warga Amerika Serikat keturunan Arab di kamp khusus sampai dapat ditentukan apakah mereka terkait dengan jaringan teroris." $^{45}$

Untuk itu, profiling sebagai sebuah bentuk interferensi atas hak atas privasi yang dilindungi berdasarkan Pasal 17 ICCPR perlu bersifat proporsional. ${ }^{46}$ Berdasarkan temuan IOM, beberapa klausul pengaman (safeguard) yang dapat digunakan dalam menjalankan profiling dan data mining intelijen yang bersifat proporsional meliputi kriteria efektivitas, dalam pengertian bahwa kemampuan pemerintah untuk memperkirakan hubungan antara profiling dengan tujuan yang diharapkan; kriteria keperluan, yakni langkah profiling tersebut merupakan upaya yang dianggap sangat perlu, dan tidak ada lagi langkah yang bersifat least intrusive, dalam mencegah kejahatan;

41 UNGA, Report of the Special Rapporteur on the promotion and protection of human rights and fundamental freedoms while countering terrorism, A/64/201l, 3 Agustus 2009, para. 37-38.

42 Ibid, para. 39.

43 B Abu Bah, "Racial Profiling and the War on Terror: Changing Trends and Perspectives," Ethnic Studies Review 29, no. esr/vol29/issl (2006): 76-100.

44 Jennifer K Elsea and Michael John Garcia, "Judicial Activity Concerning Enemy Combatant Detainees : Major Court Rulings" (2014).

45 Shaun L Gabbidon, George E Higgins, and Matthew Nelson, "Public Support for Racial Profiling in Airports : Results From a Statewide Poll" (2012).

46 UN HRC, Report of the Special Rapporteur on the promotion and protection of human rights and fundamental freedoms while countering terrorism, A/HRC/34/61, 21 Februari 2017, para. 31. 
dan kriteria pelanggaran, yakni pemerintah harus dapat memprediksi hak-hak apa saja yang dapat terlanggar dari langkah profiling tersebut. ${ }^{47}$

\section{Pengetatan Kontrol Perbatasan}

Aspek terakhir dari fungsi keimigrasian yang bertalian erat dengan pencegahan kejahatan terorisme ialah kontrol perbatasan. Dalam hal ini, perbatasan merupakan titik-titik pemeriksaan keimigrasian, baik berupa tempat pemeriksaan imigrasi (TPI) maupun non-TPI. Secara teknis, kontrol perbatasan berada di dalam kewenangan pejabat Imigrasi untuk menolak maupun mencegah seseorang untuk keluar atau masuk wilayah Indonesia; dengan ketentuan tersendiri kepada warga negara Indonesia dan orang asing. ${ }^{48}$

Dalam konteks penolakan, Pasal 28 ayat (1) mengatur bahwa "Pejabat Imigrasi berwenang menolak orang untuk keluar Wilayah Indonesia dalam hal orang tersebut: a. tidak memiliki Dokumen Perjalanan yang sah dan masih berlaku; b. diperlukan untuk kepentingan penyidikan atas permintaan pejabat yang berwenang; atau c. namanya tercantum dalam daftar pencegahan." Secara spesifik bagi orang asing, Pasal 25 UU Keimigrasian mengatur bahwa Pejabat Imigrasi menolak Orang Asing untuk masuk Wilayah Indonesia dalam hal Orang Asing tersebut: namanya tercantum dalam daftar Penangkalan; tidak memiliki Dokumen Perjalanan yang sah dan masih berlaku; memiliki Dokumen Keimigrasian yang palsu; tidak memiliki Visa, kecuali yang dibebaskan dari kewajiban memiliki Visa; telah memberi keterangan yang tidak benar dalam memperoleh Visa; menderita penyakit menular yang membahayakan kesehatan umum; terlibat kejahatan internasional dan tindak pidana transnasional yang terorganisasi; termasuk dalam daftar pencarian orang untuk ditangkap dari suatu negara asing; terlibat dalam kegiatan makar terhadap Pemerintah Republik Indonesia; atau termasuk dalam jaringan praktik atau kegiatan prostitusi, perdagangan orang, dan Penyelundupan Manusia.

Sedangkan bagi warga negara Indonesia, Pasal 27 Peraturan Pemerintah Nomor 31 Tahun 2013 tentang Peraturan Pelaksanaan Undang-Undang Nomor 6 Tahun 2011 tentang Keimigrasian mengatur bahwa: Ayat (1) Setiap warga negara Indonesia tidak dapat ditolak masuk Wilayah Indonesia. Ayat (2) Dalam hal terdapat keraguan terhadap Dokumen Perjalanan seorang warga negara Indonesia dan/atau status kewarganegaraannya, yang bersangkutan harus memberikan bukti lain yang sah dan meyakinkan yang menunjukkan bahwa yang bersangkutan adalah warga negara Indonesia. Ayat (3) Dalam rangka melengkapi bukti sebagaimana dimaksud pada ayat (2), yang bersangkutan dapat ditempatkan dalam Rumah Detensi Imigrasi atau Ruang Detensi Imigrasi. Ayat (4) Pembuktian kewarganegaraan Republik Indonesia

47 European Comission against Racism and Intolerance, General Policy Recommendation No 1 on Combating Racism and Racial Discrimination in Policing, Strasbourg, October 2007, para 32-34.

48 A Hasan, "Pengawasan dan Penindakan Keimigrasian bagi Orang Asing yang Melebih Batas Waktu Izin Tinggal di Indonesia" III:1 Lex Soc 5. Bilal Dewansyah, "The Development of Legal Policy and Legal Needs of Indonesian Immigration Law: Answered Partially, Forget the Rest," Hasanuddin Law Review 1, no. 2 (2015): 140-162, http://pasca.unhas.ac.id/ojs/index.php/halrev/article/view/88/61. 
sebagaimana dimaksud pada ayat (2) melalui pemeriksaan yang dilakukan oleh Pejabat Imigrasi.

Dalam aspek ini, fokus pengetatan kontrol perbatasan adalah pada frasa 'keraguan terhadap dokumen perjalanan seorang warga negara Indonesia'. Optimalisasi terhadap kontrol tersebut telah dilaksanakan dengan peningkatan kapasitas dan kualitas personel serta sarana untuk dapat mengidentifikasi dokumen palsu. Selain itu, mengingat fungsi ini berada pada hilir proses administrasi keluar/masuknya orang, maka pemeriksaan perbatasan memerlukan sinergi data dan informasi dengan kedua fungsi sebelumnya, yakni pengawasan dan intelijen keimigrasian. Pada titik ini, kerangka regulasi yang ada belum secara eksplisit menyediakan slot khusus bagi pemeriksa perbatasan untuk menjadikan data intelijen keimigrasian sebagai dasar penolakan maupun penangkalan orang.

\section{Model Kontrol Keimigrasian dan Peran Lembaga Lain}

Berdasarkan tinjauan terhadap tiga aspek fungsi keimigrasian sebelumnya, kajian ini merumuskan model kontrol keimigrasian yang diharapkan lebih efektif dalam mencegah terjadinya kejahatan terorisme di wilayah Indonesia. Dengan dasar pada norma dan praktik tiga aspek tersebut, secara sirkuler kerja pada masing-masing aspek dirumuskan sebagai berikut.

Model kontrol sirkuler tersebut pada prinsipnya hendak mengintegrasikan ketiga aspek dalam fungsi keimigrasian yang relevan dengan pencegahan dan pemberantasan kejahatan terorisme di Indonesia. Dalam hal ini, terdapat tiga area sirkuler yang saling terkait antara satu aspek dengan yang lain, yakni pertama, area intelijen keimigrasian dengan pengawasan keimigrasian. Dalam area ini, sirkulasi hasil / produk kegiatan di kedua aspek fungsi harus saling terkait dan saling berbagi. Dari sudut intelijen, laporan kegiatan pengawasan lapangan yang dilaksanakan oleh Pejabat Imigrasi digunakan sebagai keterangan dalam rangka operasi intelijen. Sedangkan dari sudut pengawasan, laporan hasil operasi intelijen dijadikan dasar dalam penerbitan paspor/SLP, visa, izin tinggal, serta dalam penindakan keimigrasian ketika terjadi penyalahgunaan izin orang asing. Kedua, area intelijen keimigrasian dengan pemeriksaan perbatasan. Dalam area ini, sirkulasi hasil/produk kegiatan di kedua aspek fungsi harus saling terkait dengan saling berbagi. Dari sudut intelijen, hasil penelitian latar belakang orang asing yang dilaksanakan dalam proses pemberian visa menjadi keterangan untuk fungsi intelijen. Sedangkan dari sisi pemeriksaan perbatasan, hasil laporan intelijen menjadi dasar dalam clearance exit, penolakan sementara keluar wilayah Indonesia terhadap WNA, dan penerbitan visa. Ketiga, area pemeriksaan perbatasan dengan pengawasan keimigrasian. Dalam area ini, sirkulasi hasil penelitian latar belakang orang asing dan penjamin dalam proses pemberian visa dijadikan sebagai bahan bagi pelaksana pengawasan keimigrasian, utamanya dalam konteks penindakan keimigrasian. Begitu pula sebaliknya, hasil laporan kegiatan pengawasan lapangan menjadi bahan bagi pejabat Imigrasi yang melakukan penelitian latar belakang orang asing dan penjamin ketika proses pemberian visa. 
Model kontrol sirkuler tersebut dapat menjadikan pelaksanaan fungsi keimigrasian sebagai satu kesatuan yang diharapkan secara optimal mampu mencegah dan berkontribusi terhadap pemberantasan tindak pidana terorisme. ${ }^{49}$ Secara lebih makro, dalam pelaksanaan model kontrol sirkuler ini mengisyaratkan pentingnya peran lembaga atau instansi lain dalam rangka kolaborasi dan koordinasi. ${ }^{50}$ Berdasarkan data yang diperoleh, peran Kepolisian, BNPT, NCB-Interpol, serta BIN menjadi krusial khususnya dalam penyediaan data intelijen. Data intelijen tersebut akan berkontribusi secara signifikan terhadap kinerja intelijen keimigrasian, yang pada gilirannya berkontribusi pula terhadap kedua fungsi lainnya yakni pengawasan keimigrasian dan pemeriksaan di perbatasan, dalam rangka pencegahan kejahatan terorisme di Indonesia.

\section{PENUTUP}

Berdasarkan tinjauan terhadap kasus-kasus tindak pidana terorisme yang telah diputus oleh pengadilan serta data empiris pelaksanaan fungsi keimigrasian, studi ini memperoleh gambaran tentang aspek relasional antara fungsi keimigrasian dengan fenomena kejahatan terorisme. Relasi tersebut tercermin dari tiga aspek fungsi keimigrasian, yakni pengawasan keimigrasian, intelijen keimigrasian dan pemeriksaan perbatasan. Aspek-aspek tersebut tentu dapat dirincikan ke dalam pelbagai dimensi teknis dan administratif di lingkungan Imigrasi.

Sejalan dengan logika tersebut, tinjauan terhadap aspek empiris di ketiga aspek fungsi Keimigrasian yang ada mengisyaratkan bahwa pelaksanaannya selama ini berjalan secara singuler. Dalam hal ini, ketiga fungsi keimigrasian tersebut berjalan secara terpisah dan tanpa mekanisme penghubung antara satu dengan yang lain. Padahal, mengingat dinamika kasus-kasus tindak pidana terorisme yang ada, aspekaspek fungsi tersebut wajib dijalankan di dalam satu mekanisme pencegahan yang komprehensif. Dengan demikian, kajian ini menyimpulkan sebuah model kontrol imigrasi yang bersifat sirkuler, yang berarti bahwa pelaksanaan fungsi intelijen keimigrasian, pengawasan keimigrasian dan pemeriksaan perbatasan seyogianya bersifat melingkar atau terhubung antara satu fungsi dengan yang lain.

Keterhubungan antar fungsi keimigrasian tersebut ternyata memperoleh justifikasinya secara normatif, yakni pertama, dalam rangka pelaksanaan tugas intelijen keimigrasian, pejabat Imigrasi memerlukan data laporan pengawasan keimigrasian serta hasil penelitian dalam rangka penerbitan visa dan penjamin; kedua dalam rangka pelaksanaan tugas pengawasan keimigrasian, pejabat Imigrasi memerlukan data hasil operasi intelijen serta hasil penelitian dalam rangka penerbitan visa dan penjamin; ketiga dalam rangka pelaksanaan tugas pemeriksaan perbatasan, pejabat imigrasi memerlukan data hasil operasi intelijen dan laporan pengawasan keimigrasian. Sebagai

49 SE Su, "Transnational Information Sharing, Event Notification, Rule Enforcement and Process Coordination" (2005) 1:2 Int J Electron Gov Res 1.

50 WS Deshinta, Fungsi Pengawasan Keimigrasian dalam Pengedalian Radikalisme Pasca Penerapan Kebijakan Bebas Visa Kunjungan (Semarang: Universitas Negeri Semarang, 2017). 26. 
konsekuensi, model kontrol sirkuler tersebut menghendaki adanya sharing informasi antar fungsi keimigrasian secara periodik, agar tercipta sebuah mekanisme cegah dini dalam rangka pencegahan tindak pidana terorisme di wilayah Indonesia. Lebih jauh secara makro, keterlibatan instansi atau lembaga negara lainnya, seperti Kepolisian, BNPT, BIN, dan NCB-Interpol, menjadi penting untuk memastikan berjalannya model sirkuler tersebut. ${ }^{51}$

Beranjak dari simpulan tersebut, kajian ini merumuskan beberapa poin rekomendasi kepada Menteri Hukum dan Hak Asasi Manusia untuk melakukan perubahan terhadap Peraturan Menteri Hukum dan Hak Asasi Manusia Nomor 30 Tahun 2016 tentang Intelijen Keimigrasian, khususnya agar mengatur tentang kewajiban Pejabat Imigrasi untuk menyampaikan laporan hasil intelijen kepada Direktur Pengawasan dan Penindakan Keimigrasian, Direktur Lalu Lintas Keimigrasian, dan Direktur Izin Tinggal Keimigrasian; melakukan perubahan terhadap Peraturan Menteri Hukum dan Hak Asasi Manusia No. 24 Tahun 2016 tentang Prosedur Teknis Permohonan dan Pemberian Visa Kunjungan dan Visa Tinggal Terbatas, khususnya agar mengatur tentang kewajiban Pejabat Imigrasi untuk menyampaikan hasil penelitian latar belakang orang asing dan penjamin dalam proses pemberian visa kepada Direktur Intelijen Keimigrasian dan Direktur Pengawasan dan Penindakan Keimigrasian; dan melakukan perubahan terhadap Peraturan Menteri Hukum dan Hak Asasi Manusia No. 4 Tahun 2017 tentang Tata Cara Pengawasan Keimigrasian, khususnya agar mengatur tentang kewajiban Pejabat Imigrasi untuk menyampaikan laporan hasil pengawasan kepada Direktur Intelijen Keimigrasian, Direktur Lalu Lintas Keimigrasian dan Direktur Izin Tinggal Keimigrasian.

Sebagai alternatif Direktur Jenderal Imigrasi dapat mengambil kebijakan dengan menerbitkan Surat Edaran Direktur Jenderal Imigrasi kepada seluruh Pejabat Imigrasi yang melaksanakan fungsi intelijen Keimigrasian agar menyerahkan laporan hasil operasi intelijen secara periodik kepada Direktur Pengawasan dan Penindakan Keimigrasian, Direktur Lalu Lintas Keimigrasian dan Direktur Izin Tinggal Keimigrasian, sebagai bahan pengambilan keputusan di tiga direktorat tersebut; menerbitkan Surat Edaran Direktur Jenderal Imigrasi kepada seluruh Pejabat Imigrasi yang melaksanakan fungsi pengawasan keimigrasian agar menyerahkan laporan hasil pengawasan keimigrasian secara periodik kepada Direktur Intelijen Keimigrasian dan Direktur Pengawasan dan Penindakan Keimigrasian, sebagai bahan pengambilan keputusan di dua direktorat tersebut; menerbitkan Surat Edaran Direktur Jenderal Imigrasi kepada seluruh Pejabat Imigrasi yang melaksanakan fungsi pemeriksaan perbatasan agar menyerahkan laporan penelitian orang asing dan penjamin secara periodik kepada Direktur Intelijen Keimigrasian, Direktur Lalu Lintas Keimigrasian dan Direktur Izin Tinggal Keimigrasian, sebagai bahan pengambilan keputusan di dua direktorat tersebut; menerbitkan Surat Edaran Direktur Jenderal Imigrasi dalam rangka

51 Vide Penjelasan Pasal 26 ayat (1) Undang-Undang Nomor 15 Tahun 2003 tentang Penetapan Peraturan Pemerintah Pengganti Undang-Undang Nomor 1 Tahun 2002 tentang Pemberantasan Tindak Pidana Terorisme. 
memastikan bahwa sirkulasi informasi antar aspek fungsi Keimigrasian (intelijen, pengawasan, dan pemeriksaan di perbatasan) berlangsung baik di tingkat pusat hingga ke unit-unit teknis di wilayah; menginstruksikan Direktorat Intelijen Keimigrasian untuk merancang dan menyusun database terduga terorisme yang dikelola berdasarkan data intelijen keimigrasian.

\section{DAFTAR PUSTAKA}

Aas, Katja F. Globalization and Crime (London: SAGE Publications, 2007).

Bah, B Abu, "Racial Profiling and the War on Terror: Changing Trends and Perspectives," (2006) Ethnic Studies Review 29, no. esr/vol29/issl.

Bove, Vincenzo \& Tobias Bohmelt. "Does Immigration Induce Terrorism?" (2016) J Polit.

Clayton, G. "The UK and Extraterritorial Immigration Control: Entry Clearance and Juxtaposed Control," in Extraterritorial Immigration Control: Legal Challenges, ed. Bernard Ryan and Valsamis Mitsilegas (Leiden, Boston: Martinus Nijhoff Publishers, 2010)

Demleitner, Nora V. "Immigration Threats and Rewards: Effective Law Enforcement Tools in the 'War' on Terrorism?" (2002) 51 Emory Law J 1059.

Deshinta, WS. Fungsi Pengawasan Keimigrasian dalam Pengedalian Radikalisme Pasca Penerapan Kebijakan Bebas Visa Kunjungan (Semarang: Universitas Negeri Semarang, 2017).

Dewansyah, B. "The Development of Legal Policy and Legal Needs of Indonesian Immigration Law: Answered Partially, Forget the Rest," Hasanuddin Law Review 1, no. 2 (2015): 140-162, http://pasca.unhas.ac.id/ojs/index.php/halrev/article/view/88/61.

Djalal, H. "Menentukan Batas Negara Guna Meningkatkan Pengawasan, Penegakan Hukum dan Kedaulatan NKRI" 3:2 J Pertahanan Dan Bela Negara 15.

Elsea, Jennifer K \& Michael John Garcia, "Judicial Activity Concerning Enemy Combatant Detainees : Major Court Rulings" (2014).

European Comission against Racism and Intolerance, General Policy Recommendation No 1 on Combating Racism and Racial Discrimination in Policing, Strasbourg, October 2007.

Hasan, A. "Pengawasan dan Penindakan Keimigrasian bagi Orang Asing yang Melebih Batas Waktu Izin Tinggal di Indonesia" III:1 Lex Soc 5.

IOM. International Terrorism and Migration (International Organization for Migration, 2003).

John Mueller (ed). Terrorism Since 9/11: The American Cases (Washington: The Educational Publisher, 2018).

Koslowski, Rey. "Immigration, Crime and Terrorism” in Marc R Rosenblum \& Daniel J Tichenor, eds, Oxf Handb Int Migr (Oxford University Press, 2012).

Miller, Teresa. "Blurring the Boundaries Between Immigration and Crime Control After September llth" (2005) 25:1 Boston Coll Third World Law J 81. 
Nowrasteh, A. Policy Analysis: Terrorism and Immigration (CATO Institute, 2016).

Prahassacitta, Vidya. "The Concept of Extraordinary Crime in Indonesia Legal System: Is the Concept an Effective Criminal Policy?" (2016) 7:4 Humaniora 513.

Shaun L Gabbidon, George E Higgins, and Matthew Nelson, "Public Support for Racial Profiling in Airports : Results From a Statewide Poll” (2012).

$\mathrm{Su}, \mathrm{SE}$. "Transnational Information Sharing, Event Notification, Rule Enforcement and Process Coordination" (2005) 1:2 Int J Electron Gov Res 1.

Syahrin, MA. "Menakar Kedaulatan Negara dalam Perspektif Keimigrasian" 18:1 J Penelit Huk Jure 43.

Torpey, John. The Invention of the Passport: Surveillance, Citizenship and the State (Cambridge: Cambridge University Press, 2000).

Tumlin, Karen C. "Suspect First: How Terrorism Policy Is Reshaping Immigration Policy" 92:4 Calif Law Rev 1173.

United Nations Office on Drugs and Crime. Foreign Terrorist Fighters: Manual for Judicial Training Institutes South-Eastern Europe (Vienna: United Nations, 2017).

United Nations Office on Drugs and Crime. Handbook on Criminal Justice Responses to Terrorism, Criminal Justice Handbook Series (New York: United Nations, 2009). 
96 | Model Kontrol Keimigrasian dalam Mencegah Tindak Pidana Terorisme di Indonesia

This page is intentionally left blank 